\title{
A Radical Revolution in Thought: Frederick Douglass on the Slave's Perspective on Republican Freedom
}

In Radical Republicanism: Recovering the Tradition's Popular Heritage, Bruno Leipold, Karma Nabulsi and Stuart White (eds), Oxford: Oxford University Press, 2020

\section{Alan M. S. J. Coffee}

A hallmark of the republican tradition has been its call on slaves to rise up and resist their chains. The term slave in this context goes beyond formal systems of bondage and refers to any form of subjection to arbitrary power including, for example, living under the rule of an absolute monarch. That the people were being made slaves by their rulers was the rallying call behind many of the great republican revolutions of history such as the establishment of the Roman Republic and the American War of Independence. In spite of this rhetoric, however, the reality has been less inspiring. The high standard of freedom that is promised has rarely materialised and republics have often been criticised for being hierarchical and patriarchal. We need only think of how Rome, after it had 'gained its freedom', in Livy's words, by expelling the kings and establishing the Republic, nevertheless remained a slave-based society. ${ }^{1}$ The same was true of the United States. Even where institutional slavery is abolished, former slaves are seldom integrated on equal terms as free citizens. Frederick Douglass, for example, described life for black Americans during the post-emancipation Reconstruction period as slavery no less than before. ${ }^{2}$ And over a hundred and fifty years on, black Americans still experience systematic disadvantages as citizens that can be traced back to the legacy of the slave-system.

\footnotetext{
${ }^{1}$ Livy (1962), The Early History of Rome, London: Penguin, p. 105

2 Douglass argues that though "nominally free", the former slave "was still in fact a slave, a slave to society" ("The Blessings of Liberty and Education", in The Frederick Douglass Papers, Series 1, 5 vols., John Blassingame and John McKivigan (eds.), New Haven, CT: Yale University Press, 1979, vol. 5, 619). See also "The Work of the Future" in The Life and Writings of Frederick Douglass, Philip Foner (ed.), 1976, 5 vols, New York: International Publishers, vol. 1, 292.
} 
There is, then, a clear mismatch between the republican principle of equal freedom as independent citizens for all and the reality of what becomes of republican society. I shall argue that this is not merely a tragic betrayal and failure by these states to apply their principles consistently but that there is an implicit bias in the way that republican theory has traditionally been articulated that allows socially dominant groups to control the central idea of the common good and with it to gain power over whom to include or exclude as citizens. This is not to say that republicans do not have the theoretical resources to address this problem. Indeed, there is one group of writers for whom the mismatch between rhetoric and reality has not been a surprise. This is the slaves themselves. Although republicanism is constructed around a fundamental distinction between freeman and slave and draws heavily on the classical imagery of servitude, it is notable that its theory has been entirely written by freemen. From Cicero and Livy, through Machiavelli, Milton, Harrington, Price to, in our own time, Pettit, the canon of writers to which republicans turn does not include the voice of the enslaved. In other words, those who have stood to lose most from the wrong that republicans consider to be their biggest threat have had no influence on the shape or content of the way that wrong is understood. This omission does not merely represent a missed opportunity but is a significant loss to the field of republican enquiry. Slaves have a unique perspective not only into their own condition but into the state of liberty that freemen may very easily take for granted. In particular, they have a deeply-felt appreciation of the strength and subtlety of the obstacles that prevent them from moving from slavery to freedom.

Republicans have traditionally focused on political revolutions and reforms as the means to secure freedom. Revolution may initially be violent, as in the cases of Rome and the United States, but it is always then followed by institutional reform. ${ }^{3}$ The principle of popular sovereignty is integral to the republican ideal. Ultimately, it falls to the people to hold their government to ensure that it fulfils its obligations, and so republicans have traditionally emphasised the role of accessible and transparent institutions governed by public reason

${ }^{3}$ I discuss this aspect of the republican tradition in greater detail in Coffee (2016), "Mary Wollstonecraft, Public Reason, and the Virtuous Republic", in Sandrine Bergès and Alan Coffee (eds.) The Social and Political Philosophy of Mary Wollstonecraft, Oxford: Oxford University Press, pp. 183-200. 
through which the rulers and officials can be held to account by the people in whose name they act. Each citizen should be able to make his or her voice heard in civil society and have the opportunity to appeal against any unwarranted interference with a reasonable prospect of success. For this approach to be effective, all citizens must be able to express their interests and concerns using the accepted terms of public reason. This sets a high bar for achieving freedom. Even assuming that the citizens are collectively committed to restricting their debates to what is publicly justifiable, their debates will take place within a framework of norms, values and beliefs that influence how these arguments are understood. For the members of minority or marginalised groups, this condition cannot be taken for granted and if it is not met the freedom or independence of those members is at best compromised and likely negated entirely.

Douglass argues that a political revolution is not on its own sufficient to secure freedom for all citizens. Merely changing a nation's political structures and institutions, and even its form of government, will not liberate an oppressed people where the mindset of the rest of the population remains as it was under the previous regime, and where the background social conditions prevent the new arrangements from operating effectively for everyone. In an ideologically divided and socially segregated community - such as a slavebased or formerly slave-based society - the conditions necessary for impartial and rational deliberation about the common good amongst the citizens will likely not have been met. Douglass describes the "mountain of prejudice" that black Americans faced in trying to act as free individuals, adding that if anyone, whether black or white, were to stand up for African American rights, "he will at once open a fountain of bitterness, and call forth overwhelming wrath". ${ }^{4}$ Simply admitting emancipated slaves into the society that had enslaved them by granting them formally equal standing as citizens does not secure their freedom. The slavesystem was only able to flourish because society had been organised around its acceptance and its being perpetuated. That frame of mind in the majority of citizens continued to persist long after the slave-system itself officially came to an end. Before the slaves can be genuinely free, Douglass argues, the revolution must be completed. Alongside the revolution in political rights, there must be a corresponding revolution in social attitudes. The scale of what this

\footnotetext{
4 "Our Destiny is Largely in our own Hands" in Papers, vol. 5, 63.
} 
entails should not be underestimated. What is required "is nothing less than a radical revolution in all the modes of thought which have flourished under the blighting slave system". ${ }^{5}$ The task is enormous. "We will", Douglass predicted before the end of the war, "reconstruct the whole fabric of Southern society". ${ }^{6}$ Unlike the prosecution of a war, however, there is no shortcut to victory. Douglass warns us that "there is no such thing as immediate Emancipation either for the master or for the slave. "Time, experience and culture", he concludes, "must gradually bring society back to the normal condition from which long years of slavery have carried all under its iron sway". ${ }^{7}$

In referring to republicanism, I have in mind the neo-republican tradition that was so influential in shaping the course of first American independence and then subsequently taken up explicitly by the abolitionist movement as providing the rationale for emancipation. ${ }^{8}$ Within this tradition the central organizing principle is that of freedom defined as independence from arbitrary rule. This ideal is what makes popular sovereignty possible since only an independent citizenry is truly able to express its will with integrity and free from either coercion or the need to self-censor and appease others. Independence is understood as membership within a community as an equal governed under a law created by the people or its representatives that is required to reflect fairly the shared interests of all those it represents. ${ }^{9}$ Articulated this way, freedom is itself a complex social ideal that encompasses and brings together several other political values, including equality, citizenship, membership, the rule of law. While republican institutions are responsible for holding these separate elements together, ultimately they are dependent on the disposition and attitudes - or civic virtues - of the citizens themselves.

\footnotetext{
5 "Work of the Future", 292.

6 "Work of the Future", 291.

7 "Work of the Future", 292.

${ }^{8}$ See Bernard Baylin (1992) The Ideological Origins of the American Revolution, Cambridge, MA: Belknap Press, especially pp. 230-319 and Quentin Skinner (1998), Liberty before Liberalism, Cambridge: Cambridge University Press.

9 See also Coffee (2017), “Catharine Macaulay's Republican Conception of Social and Political Liberty", Political Studies, 65 (4), 844-59.
} 
The structure of this chapter is as follows. In the next section, I set out some core philosophical principles of neo-Roman republicanism, focusing on its central commitment the notions of independence, equality and the common good. These principles give republicanism both a radical inclusive strand and a conservative strand that seeks unity and stability. The tension between these strands is resolved by appeal to the concept of citizen virtue, which I discuss in section three. Virtue itself requires a thoroughgoing commitment to equality across all important dimensions of social life, economically, politically and socially. An unequal or hierarchical society cannot exist long as a free state because any substantial inequalities within a population will inevitably corrupt the virtue that is necessary for freedom to persist. Over time, Douglass argues, inequality and hierarchy will inevitably lead to the corrupting of a society's culture as it adapts to reinforce and normalise these conditions as part of the natural order. This corrupted culture is the one that is in place both before and after a popular revolution such as the one that brought America its independence as well as the proclamation that emancipated its slaves.

In section four I give Douglass's argument showing how the structure of motivation in radically unequal societies leads to not only the creation of social prejudices but a complete breakdown in the public commitment to reasoned argument through the creation of a partisan propaganda war between rival factions eager to seek the advantage. In the final section we see that before there can be any hope of liberation for the formerly enslaved there must be a wholesale revolution in the thought patterns that went before. All vestiges of the former ways of thinking and prejudices must be overturned and new norms, values and practices must be collaboratively made by both the old and new members of the citizenry. In making the argument for the importance of cultural change, I do not mean to suggest that economic and political changes are not equally necessary. Each is important both individually and in combination with the others. I make the cultural argument, rather, because it has been under-emphasised by republicans and is theoretically significant. I believe that Douglass has made a valuable and lasting contribution to republican thinking in this respect.

\section{II}

The republican promise is not only of freedom but of a robust guarantee of protection against arbitrary rule. The aim is to secure individual independence within a collective system of laws 
and institutions in which everyone has a stake and is treated equally. The condition of equality is vital. The reason is that if any group of people are treated more favourably than others then they have an unfair advantage that can lead to them circumventing the provisions of law and usurping power. The rest of the population would then be dependent on that more powerful group and would therefore no longer be free.

Republican freedom is built around the core ideal of the common good (which is the object of popular sovereignty and that which constrains its actions). This is the standard against which arbitrary power is judged. Any power which is not constrained to act only in the collective interests of all the people, as they themselves understand it, is deemed to be arbitrary. It is a threat to freedom and thereby illegitimate. It follows, then, that the central task facing republicans is to identify what the common good is. This ideal must satisfy at least two conditions, being both inclusive and stable. This dual requirement gives republican theory both a radical and conservative character that often pulls in different directions. On the radical side, republicans must continually strive to bring into the citizenry all those who have been excluded. Historically this meant extending the franchise to include the working classes, minority religious groups, women and ultimately to slaves themselves. Inclusivity is entailed by the logic of republicanism but it also has a pragmatic basis. Anyone who is subject to the coercive power of government but whose interests are not represented in or protected by its laws is ruled arbitrarily and is thereby, in republican terms, a slave. As we shall see, the mere presence of slaves has a destabilising effect on the freedom of all the citizens. The conservative strand in republicanism represents a principle of stability and sustainability seeking to forge unity out of diversity by creating coherent and viable idea of the common good that will command the loyalty of the citizens.

Although they may pull in different directions, the radical and conservative sides to republicanism each act as a check on the other, curbing any excesses that might destabilise the nation. To emphasise inclusivity without unity, it can be argued, would be to invite factionalism and so threaten the survival of the republic. For those republican states that have endured, however, there is a corresponding danger that the conservative strand will become too powerful imposing an ideal of unity on the population that is not reflective of its diversity and firmly resists any attempt at dissent from the prevailing outlook. From the very earliest times, republican writers have fixated on the dangers of faction to the security of the state 
urged that the people must first become united, even at the cost of freedom, until such time as they are ready for freedom. "Premature liberty" (from the Tarquin dynasty), says Livy, "would have been a disaster: we should have been torn to pieces by petty squabbles before we had ever reached political maturity, which, as things were, was made possible by the long quiet years under monarchical government". ${ }^{10}$ Nevertheless, even in this case we can see that the inclusivity and unity principles were working together. What became the people of Rome began as a diverse "rabble of vagrants, mostly runaways and refugees". Roman spirt and patriotism was something that they developed together.

When the American slaves were emancipated the same cannot be said. There had been no common culture created by both white and black Americans. Rather the black population was being admitted into a white society that had already been established and whose core values and structures were no longer available to be discussed or challenged. Any appeal, as was often made, to the importance of unity around the common good and respect for the values of the republic must first demonstrate that those ideals are fully inclusive of the interests and perspectives of the whole population. It is at this point that Douglass begins the argument that I set out in this chapter. The enormous difference in power and influence between former slaveholders and vested interests on the one hand and freedmen on the other allows the former to create a conceptual baseline from which they can control how the common good is understood, and so to preserve their own interests under the guise of maintaining unity. Minority and marginalised voices come to be perpetually excluded. The result is a corrupted, reactionary form of republicanism - "not a true democracy, but a bastard republicanism" - that belies its radical aims of giving freedom to the oppressed. ${ }^{11}$

The most fundamental task for republicans, then, is to identify what the common good of the citizens is. ${ }^{12}$ The second task is to ensure that this ideal is used in the governing of the

10 Livy, Rome, p. 105.

${ }^{11}$ Douglass, "Slavery and America's Bastard Republicanism" in Papers vol. 1, p. 78.

12 From a theoretical perspective, knowing what the common good represents is of paramount importance because it is the reference point around which freedom, arbitrariness and virtue are all understood. This much said, of course, the common good is not a static ideal but something which constantly shifts and which, therefore, must be continually both created 
people. For both of these tasks, republicans have traditionally placed their trust in the effectiveness of accessible and transparent institutions governed by public reason through which the rulers and officials can be held to account. So long as there is a robust institutional structure in place, the argument goes, each citizen should be able to make his or her voice heard in civil society and have the opportunity to appeal against any unwarranted interference with a reasonable prospect of success. Crucial to the success of this approach is a requirement that both the general population and those who regulate the institutions can shed their personal perspectives and judge arguments on merit according to the standards of public reason. Historically, republicans have been confident that this condition can be met. By Douglass's time, this confidence often reflected the strong influence of natural law thinking that had become fused with republicanism from the seventeenth century and according to which the moral principles that govern the world are understood to be available to those who apply their faculties of reason correctly. ${ }^{13}$ While Douglass himself should be regarded as a natural law philosopher he remains highly aware of the human propensity to self-deception and the uncritical way in which most of us absorb ideas from our background culture. He also emphasises the enormous struggle minority and outsider groups have in being taken seriously when the challenge prevailing attitudes.

The standard required for a person to be considered independent is extremely high. Individuals must be protected against arbitrary power in any form, including not only political power but also economic, physical and even social power in the form of a person's standing

and discovered. In that case one might say that the most fundamental task for republicans is to identify the processes by which the citizens can come to define or discern their common good together.

${ }^{13}$ See Furstenberg, Francois (2002), "Beyond Freedom and Slavery: Autonomy, Virtue, and Resistance in Early American Political Discourse", The Journal of American History, 89 (4): 1295-1331. For a discussion of the role of natural law principles in Douglass's thinking, see Peter Meyers (2008) Frederick Douglass: Race and the Rebirth of American Liberalism, Lawrence, KS: University Press of Kansas, 49. For an example of these principles at work in a republican revolutionary writer, see for example in James Otis, The Rights of the British Colonies Asserted and Proved, Boston, Ma: J. Almon, 1764. 
within the community. This last form of power is very difficult to define. It is also very difficult to prove that it has been breached and still harder to enforce. Nevertheless, people without social standing have no effective voice in representing their perspectives and in defending their interests. This makes them dependent rather than independent. They must rely on other people taking a sympathetic view of their condition rather than standing on their own feet in their own right. That is not freedom. Douglass argues is that this is what necessarily happens when a system of slavery is overturned. In a slaveholding society, slaves have no social standing. The mere fact of a change of government does not change that. The former masters, he says, "will carry into the new relation of liberty much of the insolence, caprice and pretention exercised by him while the admitted lord of the lash". ${ }^{14}$ The risk for freedmen, therefore, is that they will simply "exchange the relation of slavery to individuals, only to become the slaves of the community at large, having no rights which anybody is required to respect".

If political equality is a condition for republican freedom as independence, then so too is equality of standing for without this equality under law is made ineffective. "It is our lot" Douglass laments, "to live among a people whose laws, traditions and prejudices have been against us for centuries, and from these they are not yet free. To assume that they are free from these evils simply because they have changed their laws is to assume what is utterly unreasonable and contrary to facts". ${ }^{15} \mathrm{He}$ adds that "the color line meets him everywhere and in a measure shuts him out from all respectable and profitable trades can callings. In spite of all your... laws he is a rejected man". The acceptance of others as equals cannot be

\footnotetext{
14 "Work of the Future", 292.

15 Douglass, "Parties were made for Men, Not Men for Parties" in Papers vol. 5, 92.
} 
imposed. ${ }^{16}$ It relies on the character and disposition - or virtue - of the citizens which is why virtue as well as equality is a constitutive and necessary part of the republican ideal. ${ }^{17}$

\section{III}

At its most basic, 'virtue' in the civic republican sense with which we are concerned simply refers to any behaviour that supports and promotes the public good and so benefits the republic. ${ }^{18}$ There is no definitive or settled account of what specific behaviours this will include. This is not surprising given the wide range of ideals contained in the republican ideal of freedom and the diversity of temperaments and qualities that are required in a largescale democracy. Not every citizen, of course, can be expected to demonstrate all the potential virtues in a single life. The personal characteristics associated with a radical reformer, for example, will often likely be both psychologically and politically incompatible with those that make a successful governor or democratic politician. It would be one thing to have the skills

${ }^{16}$ A prevailing view in Douglass's time was that 'social equality' could not be legislated. The fear of many white people at the time was that granting legal and political equality to black Americans would lead to demands that their social status would also be raised and that black people would first demand to be respected and esteemed as if they were white and then want to mix freely amongst them in their social circles. Indeed, the phrase "social equality" was often invoked as a pejorative slur to knock back progressive initiatives, rather as the term "political correctness" can be used today. While Douglass is often sceptical about the notion of "social equality" described in these terms, he insists that if you are to use it you must draw a clear distinction between social (attitudes) and civil equality, the latter of which must rest on a secure legal basis (See for example, Douglass, "What shall be done with the Negro?", New York Times, 16 May 1863, and "The Civil Rights Case", in Writings vol. 4, 402).

17 On the relationship between freedom, equality and virtue, see Coffee (2013), "Mary Wollstonecraft, Freedom and the Enduring Power of Social Domination", European Journal of Political Theory, 12 (2): 119-21.

${ }^{18}$ See for example Machiavelli's use of virtù in The Prince, in The Chief Works and Others, A. Gilbert (trans.), 3 vols., Durham: Duke University Press, 1965, vol. 1, 66. I discuss this idea further in Coffee, "Virtuous Republic", 188. 
and temperament to agitate tirelessly and fearlessly for justice and reform and quite another to have the diplomacy and tact necessary to create consensus and unity through compromise and to establish common ground.

Over the course of his long career, Douglass himself has often been accused by critics of shifting from being radical to being conservative and that this demonstrates on his part, variously, a lack of conviction, a change of mind, or an intellectual inconsistency. ${ }^{19}$ Philosophically, however, there is no necessary contradiction between these dispositions as republicans are called on to be both radical and conservative. ${ }^{20}$ Indeed, the virtue of pragmatism - doing whatever is necessary in the pursuit of freedom even at the expense of principle - is itself integral to the republican ideal. ${ }^{21}$ Douglass was always resolute in his

19 On Douglass's radicalism see, for example, Leslie Goldstein (1976), "Violence as an Instrument for Social Change: The Views of Frederick Douglass (1817-1895)", The Journal of Negro History 61 (1), 61-72, James Stauffer (2004), The Black Hearts of Men, Cambridge, Ma: Harvard University Press, James Oakes (2007), The Radical and the Republican: Frederick Douglass, Abraham Lincoln, and the Triumph of Antislavery Politics, New York: W. W. Norton and Co. Peter Myers (2013) gives a balanced discussion of the complexities of Douglass's career ("Frederick Douglass on Revolution and Integration: A Problem in Moral Psychology", American Political Thought 2 (1), 118-146). On the uneasy relationship between Douglass's early radicalism and later conservatism, see for example Waldo Martin (1984), The Mind of Frederick Douglass, Chapel Hill: University of North Carolina Press.

${ }^{20}$ We should be careful to distinguish Douglass's philosophical republicanism in the sense of a commitment to freedom as independence, as I am using it in this chapter, from his membership of the Republican Party. Although it must be remembered that the Republican Party was a progressive and anti-slavery party in its origins even during Douglass's lifetime the lines between the parties on progressive issues were becoming murky.

${ }^{21}$ While the republican tradition is a broad church in terms of the particular values and principles that motivate its various adherents, these are organised and given structure within the overarching goal of pursuing freedom as independence, or non-domination. To that extent, pursuing freedom is the ultimate aim that constrains and directs one's adherence of any other values. As a pragmatic matter if one has to set aside an important principle for the 
opposition to slavery and acknowledged that slaves had the fight for their freedom. He praises Madison Washington for his rebellion and in his own showdown with his former master, Covey, Douglass himself risked death or, worse, being sold further on South into even harsher slavery. ${ }^{22}$ But slaves are not always advised to fight in this way if the expected costs in terms of reprisals and bloodshed outweigh the benefits and likelihood of success. So while Douglass admired John Brown for his unsuccessful raid at Harper's Ferry, and conceded that someone had to do it, he did not join Brown in the attack. ${ }^{23}$ Seen through a republican lens Douglass's stance need not represent weakness or double standards so much as belief in the division of labour required to build lasting freedom.

A principle in Douglass's thought that unifies his radical and conservative leanings is the republican idea that freedom always comes through rather than despite government. An example of this can be seen in Douglass's support for General Grant's proposal to annex Santo Domingo (now the Dominican Republic). ${ }^{24}$ Douglass dismisses the claim such an act would

sake of freedom (e.g. to break a law to preserve freedom under the rule of law) then not only is that permitted but this pragmatic spirit may be counted as a 'virtue' in itself.

${ }^{22}$ Douglass, "The Heroic Slave" in Uncle Tom's Cabin, Harriet Beecher-Stowe, Oxford: Oxford University Press, 1998, 482-520, and My Bondage, My Freedom, London: Penguin, 2003, 1907.

${ }^{23}$ Life and Times, 195-7.

${ }^{24}$ Life and Times, 296-9. Douglass's support for the annexation of Santo Domingo in 1871 represented a reversal of his earlier opinion which can be traced as far back as 1846 when he wrote against the plan from his tour of the British Isles. We can only speculate on the exact reasons he had for changing his mind, but certainly the decision to support the President's plan cost him personally in his reputation as a black leader. I neither endorse nor condemn his position here but only note the republican structure of the arguments he made, couching them in terms of the importance of robust freedom from domination, or independence. The United States had long had an eye on Santo Domingo for both strategic military and commercial reasons. However, while the geo-political case had not changed in the intervening 25 years, Douglass's own situation had. In 1846 he was a fugitive and freedom fighter whereas in 1871 he was a diplomat with responsibilities for government policy. Understandably, 
degrade and humiliate a people of colour who had a right to be a sovereign nation responding that, on the contrary, such an alliance would bring genuine freedom. No nation of that size could survive let alone flourish in isolation and so to join a larger union of states as an equal under the same set of laws "would give it peace, stability, prosperity, and civilization" and since the government of Santo Domingo agreed, there was no more dishonour in this arrangement than in admitting Kansas or Nebraska to the union. ${ }^{25}$ Douglass's general view, then, is that "government is better than anarchy, and that patient reform is better than violent revolution". ${ }^{26}$ But government must be legitimate if not necessarily fully republican. Before the Civil War, he argues, the American government was not legitimate but had been usurped by slave power which had distorted the constitution and was impervious to moral argument. Under those conditions, armed resistance is called for ("power" he says "concedes nothing" without a struggle). ${ }^{27}$ Once the black population was admitted to the citizenry, even under appalling conditions, however, then there was a legal and constitutional route to justice that prevented him from ever again advocating violence.

For this constitutional route to be viable there must be a commitment on the part of the citizenry. This requires two specific and general virtues that must be sufficiently prevalent amongst the population. Both virtues are hindered fatally by the biased conceptual system and framework beliefs and ideas made available under the slave system. The first is that every citizen must respect the legitimate and equal standing of one's fellow citizens. When slaves are emancipated and admitted into the citizenry it is little wonder that this condition is not

scholars differ on how and to what extent these factors influenced his thinking (for different takes on this, see Daniel Brantley (1984), "Black Diplomacy and Frederick Douglass' Caribbean Experiences, 1871 and 1889-1891: The Untold History", Phylon 45 (3), 197-209 and Merline Pitre (1977), "Frederick Douglass and the Annexation of Santo Domingo", The Journal of Negro History 62 (4), 390-400). My own view is that whatever impact external factors had on Douglass's thinking, we should take seriously his commitment to the republican principles he espouses in expressing his position.

${ }^{25}$ Life and Times, 297-8.

26 Life and Times, 397.

27 Douglass, "West India Emancipation" in Writings, vol. 2, 437. 
easily met, all the more so if the situation was imposed on an unwilling population after a prolonged and bloody conflict. Most of the existing citizens were used to viewing slaves with a mixture of pity and contempt and few have ever had to take slaves' interests into account, make sacrifices or concessions on their account or enter into any discourse with them. If emancipated slaves are not accepted on equal terms as citizens then they are not free no matter what their legal standing is. Douglass himself remarked how much freer he felt in England - a monarchy - than in America under its formally impeccable republican institutions. ${ }^{28}$ The reason lay in the respective levels in each country of the virtue of respect. America was divided by colour prejudice into a rigid caste system that replicated the previous slave system whereas the English, in Douglass's experience, "saw in the negro a man, a moral and responsible being". ${ }^{29}$ To be accepted in this way is a precondition for being socially free.

Even assuming a people can accept each other as compatriots they must then govern themselves in an inclusive and representative manner. To do this, they must come together to discuss their shared interests and so to establish an idea of the common good. A second virtue, then, that is necessary for republican freedom is that individuals should possess a capacity and willingness to constrain their conduct according to the principles of public reason. ${ }^{30}$ For citizens, this is a cardinal virtue because reasoned argument represents the most fundamental defence of freedom. A condition of freedom is that it is resilient, secure against any contingency that might undermine it. To be governed by any standard less than by reason itself was held to be unreliable. If people behave justly only because they are well-disposed towards each other, for example, there was nothing to say that this attitude must necessarily continue. Reason, republicans have traditionally claimed was the only truly non-arbitrary

\footnotetext{
${ }^{28}$ My Bondage, 271; Life and Times, 400.

${ }^{29}$ Life and Times, 280 (see also James M'Cune Smith's introduction to My Bondage). We should not make too much of Douglass's comments about England. Although he admired England for many things, not least for its actions in ending slavery as well as his own treatment there, he condemned England's treatment of the Irish which often resembled slavery. Racism, prejudice, and self-interest, Douglass argued, can be found everywhere but uniquely in America is the racial caste system that derives from slavery.

${ }^{30}$ Coffee, "Virtuous Republic", 188.
} 
standard by which to establish the principles of government. So long as the best reasons, considered in the light of the agreed common good, are required to carry the day then we can be sure of our freedom and are therefore independent. If this condition does not hold, we cannot be certain that our interests will be protected and so we become dependent on the goodwill of those with the power to decide.

What Douglass shows is that in a slave society virtue, the ability to reason impartially, has already been corrupted. "Prejudice" as he puts it, "sets all logic at defiance. It takes no account of reason or consistency". ${ }^{31}$ The motivational structure of dominating relationships, he argues, makes deceit and self-interest, rather than truth and the common good, the most prudent course of behaviour. This leads to the creation of a culture of prejudices that support the slaveholding classes. It is in the nature of cultural prejudices that eventually they come to be accepted as the norm, and even as obvious natural truths. The process of reasoning takes place within a conceptual framework that furnishes us with the necessary intellectual and moral resources. In a slaveholding state that framework is constructed around the central principles of slavery. The values of slavery provide the anchor point around which all other ideas, values and beliefs must be distorted and manipulated in order to fit ("when they assumed that slavery was right, they easily saw that everything inconsistent with slavery was wrong"..) 32 This background remains in place even where the institutional apparatus of bondage has been dismantled. Very few people, however, are aware of the effect that their social and cultural environment has on their ability to think independently. The result is that, while debate about the common good might have seemed to the citizens involved to have been conducted in neutral and impartial terms, in reality there was an irresistible bias towards what had gone before.

\section{IV}

One of the most effective ways to prevent slaves from being liberated and joining the citizenry is to deny that they can ever possess the virtue necessary for them to become citizens. Freeing slaves would therefore be a danger to the republic as well as quite possibly an unkindness to

\footnotetext{
31 Life and Times, 441.

32 "The United States cannot Remain Half-Slave and Half-Free", Writings, vol. 4, 364.
} 
the slaves themselves who would find themselves ill-equipped to cope with their freedom. Indeed this was a standard republican position that stretches back to its Roman origins. ${ }^{33}$ Douglass is all-too aware of the self-serving nature of this argument. "These objections" he notes, "are often urged with a show of sincere solicitude for the welfare of slaves themselves" while simultaneously invoking pity and stoking fear: "what will you do with them? they can't take care of themselves... they would not work; they would become a burden upon the State, and a blot upon society; they'd cut their master's throats; ... they would necessarily become vagrants, paupers and criminals, overrunning all our alms houses, jails and prisons". ${ }^{34}$

Although popular prejudice had it that people of African descent naturally lacked the requisite intellectual and moral capacities to become virtuous this position has no basis in republican logic as I have articulated it in this chapter. ${ }^{35}$ The classical republican claim was that slaves internalised a 'slavish' or 'servile' mentality as a result of their condition. Virtue had to be learned and this required the development of a strong character, something that was incompatible with the condition of slavery in which individuals have no control over their situation and do not take ultimate responsibility for their decisions. Rather, slaves survive by

${ }^{33}$ On the classical roots of this idea and its place in republican history, see Quentin Skinner (2008), "Freedom as the Absence of Arbitrary Power" in Republicanism and Political Theory, Cécile Laborde and John Maynor (eds), Oxford: Blackwell, 92.

${ }^{34}$ Douglass, "What shall be done with the Slaves if Emancipated?" in Writings, vol. 3, 188.

35 George Fitzhugh summarizes a popular view, "Children cannot be governed by mere law; first because they do not understand it, and secondly because they are so much under the influence of impulse, passion and appetite, that they want sufficient self control to be governed by the distant and doubtful penalties of the law. They must be constantly controlled by parents or guardians, whose will and orders shall stand in place of law for them... nor will the government of mere law suffice for the individual negro. He is but a grown up child, and must be governed as a child", (Sociology for the South, Richmond, Va: A. Morris, 1954, pp. 823). Interestingly, he concedes that the this assertion is more a matter of prejudice than of reasoned argument, adding that "we shall not dwell on this view, for no one will differ with us who thinks as we do of the negro's capacity, and we might argue till dooms-day, in vain, with those who have a high opinion of the negro's moral and intellectual capacity". 
using cunning and flattery, by lying low and staying out of trouble, or by simply obeying mindlessly. These self-serving behaviours were incompatible with the integrity demanded of citizens, which required them to stand firm on principle and to act courageously for the good of all. Over time, slaves as a class were thought to lose the capacity for virtue altogether. ${ }^{36}$

Historically, republicans have both pitied and despised slaves. ${ }^{37}$ They pitied them for the unfortunate condition in which slaves found themselves and yet despised them for what they had become. This latter reaction was very deep and there was widespread revulsion at the very suggestion that beings so degraded could one day walk among them as political, still less social, equals. Although the possibility of manumission in particular and exceptional individual cases has been recognised in republican societies from the earliest times, the prevailing view that slaves were generally incapable of acquiring virtue ruled out the idea that they could be emancipated as a class and absorbed into the citizenry. The formal argument that slavery corrupts virtue, however, does not prove what its proponents claimed. Republican theory holds that the process of corruption in both directions affecting both parties to a dependent relationship, dominator as much as dominated. If slaves become obsequious and servile, then masters are prone to arrogance, laziness and complacency. Historically, some of the most damning passages in republican literature have been aimed at the degenerate aristocracy, bloated and brought down by the excesses of arbitrary power. ${ }^{38}$ Furthermore, not only does slavery corrupt both masters and slaves in equal measure but this corruption has a propensity to spread. Like rust, to use Madame Roland's image, the process of corruption extends imperceptibly but inexorably beyond particular relationships to corrode

\footnotetext{
${ }^{36}$ See Quentin Skinner, "Arbitrary Power", 92-3.

37 Douglass is acutely aware of the implications of this tendency. First, he notes that the "intense hatred of the colored man" derives from the fact that colour has for so long been "coupled I the mind with the degradation of slavery and servitude" ("Prejudice against Color" in Writings, vol. 3, 129). He also believes that "Human nature is so constituted, that it cannot honour a helpless man, though it can pity him, and even this it cannot do long if signs of power do not arise" (My Bondage, 180).

${ }^{38}$ A fine example is Mary Wollstonecraft's analysis of the causes of the French Revolution in A Vindication of the Rights of Men.
} 
the virtue of society as a whole as the moral community is subverted and replaced by an arena of competing private interests. And like rust, the process once started is difficult to arrest or reverse. ${ }^{39}$

Douglass does not deny that slaves lack virtue. On the contrary, he regards it as a logical truth. "When you have deprived man of the liberty of acting freely", he argues, "you disqualify him for obeying the law of God", a precondition for virtue. ${ }^{40} \mathrm{~A}$ slave cannot have virtue because "his conscience, his intellect, his affections are all set aside by the master", 41 whose sole prerogative it is to decide "what is right and wrong, virtue or vice". ${ }^{42}$ The salient matter, Douglass reminds us, is not the supposed moral failings of the slaves - moral agency has been denied them - but that of the slaveholders who are "every hour the violator of the just and inalienable rights of man". ${ }^{43}$ There is another specifically republican reason for holding that slaves necessarily lack virtue. Virtue is by definition reserved for citizens since it concerns the defence of their own common good from which slaves are officially excluded. Not only are slaves outside the republic but they are violated by it. Far from being morally required to uphold the society of their oppressors, slaves have a moral reason to undermine and even to seek to destroy it. ${ }^{44}$

The fundamental problem to be addressed concerning the corrupting effect of arbitrary power was not, on Douglass's account, the internalization of unvirtuous behaviour

39 "The rust of barbarity covers their proud masters and ruins them together. The poisoned breath of despotism destroys virtue in the bud" (in Sandrine Bergès, "A Republican Housewife: Marie-Jeanne Phlipon Roland on Women's Political Role", Hypatia, 2015, 31 (1), 111).

40 Douglass, "The Relation of the Free Church to the Slave Church" Papers, vol. 1, 189-95.

${ }^{41}$ Douglass, "American Slavery, American Religion, and the Free Church of Scotland" Papers, Series 1, vol. 1, 273.

42 Douglass, “A Simple Tale of American Slavery”, Papers, vol. 1, 399.

${ }^{43}$ My Bondage, 197.

${ }^{44} \mathrm{~A}$ common theme in the abolitionist arguments from the late eighteenth century was of slavery as a state of war, being an attack on the natural right of freedom. For the influence of this idea on Douglass and those around him, see Stauffer, Black Hearts, 21. 
but the structure of motivation that domination creates. By putting slaves and slaveholders at odds with each other a system of incentives is set in place that encourages and rewards prejudices based on self-interest and punishes rational deliberation about the common good. So powerful is this effect that eventually the entire population is sucked into this struggle preventing the possibility of impartial debate and thereby dealing a fatal blow to the possibility of a free republic. Mistrust, deception and false appearances, Douglass shows, are central to the slave system, not just between masters and slaves, but also between slaves and eventually between all those who find themselves complicit in slaveholding society.

Notwithstanding their public statements to the contrary, at the pragmatic level slaveholders knew perfectly well that they were dealing with real and intelligent people. "It is the interest and business of slaveholders to study human nature", Douglass observes, "and many of them attain astonishing proficiency in discerning the thoughts and emotions of slaves." 45 Slaveholders know that the threat of rebellion is real. They know that, being rational, slaves will act in just the same ways as they themselves would do in their position. "So much intellect as the slaveholder has around him", Douglass argues, "requires watching. Their safety depends upon their vigilance. Conscious of the injustice and wrong they are every hour perpetrating, and knowing what they themselves would do if made the victims of such wrongs, they are looking out for the first signs of the dread retribution of justice", The slaveholders must, therefore, stay one step ahead and continually find "new means to keep their slaves in subjection". ${ }^{46}$ The stakes are high. No one can afford to relax or to take their eye off their enemy, for "slavery never sleeps or slumbers". ${ }^{47}$

A complex psychological battle develops between slaves and slaveholders. Neither side reveals their true hand, each attempting to distort appearances to suit their purposes. On the slaves' side, they must not even reveal themselves to be intelligent beings, conforming instead to a docile, compliant and ignorant racial stereotype. Nothing they say or do must be what it appears. Slaves, for example, speak to each other in code. "We had several words" Douglass recalls, "expressive of things, important to us, which we understood, but which,

\footnotetext{
${ }^{45}$ My Bondage, 202.

${ }^{46}$ Douglass, "International Moral Force Can Destroy Slavery", Papers, Series 1, vol. 1, 184.

${ }^{47}$ Douglass, "Farewell Speech to the British People" in Writings, vol. 2. 215.
} 
even if distinctly heard by an outsider, would convey no certain meaning" ${ }^{48}$ It was not only their language that slaves had to watch, "unusual sobriety, apparent abstraction, sullenness and indifference-indeed, any mood out of the common way-[would] afford ground for suspicion and inquiry". ${ }^{49}$

On the slaveholders' side, while they had the physical power to restrain their slaves, ultimately, what kept them in power was their ability to manipulate and control ideas, starting with their own slaves but eventually coming to infiltrate the whole of society. This they did with a relentless and ruthless thoroughness. "There they stand", Douglass says of the proslavery lobby, "with all their education, with all their religion, with all their moral influence, with all their means of co-operation - there they stand, sworn before God and the universe, that the slave shall continue a slave or die".${ }^{50}$ Slaves had none of these advantages. They were denied an education (indeed one of the few crimes that carried the death penalty for a white person was to teach a slave to write), their religious instruction consisted of one commandment, "slaves obey your masters", and even where a slave to think of speaking up, there was no outlet. "Where may he assemble? Where are his newspapers?" Douglass asks, concluding that "there comes no voice from the enslaved". ${ }^{51}$

It was not enough, however, merely to keep their slaves quiet. The task of subjecting four million people - around a sixth of the US population - required that no dissent would be possible. ${ }^{52}$ Slaveholders achieved this by infiltrating and ultimately by taking over each of the important cultural and political institutions of the state. Eventually, the interests of the slaveholders became "woven and interwoven with the very texture-with the whole network-of our social and religious organizations". ${ }^{53}$ Douglass adds that "slavery has not only framed our civil and criminal code, it has not only nominated our presidents, judges, and

\footnotetext{
${ }^{48}$ My Bondage, 205.

${ }^{49}$ My Bondage, 202.

50 “Farewell", 208.

${ }^{51}$ Douglass, "The Nature of Slavery" in My Bondage, 331.

52 Douglass refers to America's as a "bastard republicanism that enslaved one sixth of the population" (“Bastard Republicanism”, 81).

53 "Farewell", 216.
} 
diplomatic agents, but it has also given to us the most popular commentators on the Bible in America". With the wholehearted endorsement of the church, slaveholders were able to colonise the moral high ground and brand their opponents as troublemakers who would threaten the unity of the republic itself, thereby making the task of reform much more difficult.

The success of the slaveholding powers in coming to dominate and control public opinion allowed the first kind prejudice discussed above, "that the Negro belongs to an inferior race" to flourish. This irrational belief, made inevitable by the process he has articulated, acts as an enabler for all the social barriers erected against black people taking their place as citizens. It is, he argues, "is the apology, the philosophical and ethnological apology for all the hell-black crimes ever committed by the white race against the blacks and the warrant for the repetition of those crimes through all times". ${ }^{54}$ The argument that blacks deserve their treatment is, Douglass goes on to show, as unsound as it is "monstrous". That the argument gained such traction, he concludes, demonstrates the profound effect of prejudice that stems from a false system of beliefs but which escalates into an intense hatred on people's ability to think and reason with any degree of impartiality. "That men can resort to" the argument that negroes are inferior, he concludes "shows that when the human mind is once completely under the dominion of pride and selfishness, the reasoning faculties are inverted if not subverted". 55

\section{V}

While black people have the most to fear from the breakdown in public reason and the ceding of power to proslavery interests, Douglass emphasises that the end result is that both races will become unfree. "A class of tyrants", he argues, will be created, "in whose presence no man's Liberty, not even the white man's Liberty would be safe. The slaveholder would then

\footnotetext{
54 "The Present and Future of the Colored Race in America" in Writings, vol. 3, 355. 55 "Colored Race", 356.
} 
be the only really free man of the country" ${ }^{56}$ If black people are the slaves then the nonslaveholding whites are merely their "miserable watch dogs".

No state, according to Douglass, can remain for long "half slave and half free" ${ }^{57}$ It "must be all one or the other". The logic of each side, freedom and slavery, is to undermine the other and eventually to displace it entirely (or more forcefully, liberty "must either cut the throat of slavery or slavery would cut the throat of liberty"). ${ }^{58}$ Douglass traces the events that led up to the Civil War, showing how the culture of slavery systematically undermined the culture of freedom up to the point of war itself. In the aftermath although the slave powers were defeated their culture was not. This meant that comparatively little had changed regarding the freedom of the nation. As we noted above, Douglass considered that the black population had merely exchanged one form of servitude for another. Just as significantly, the process of cultural and conceptual erosion continued from where it left off systematically rolling back freedom's gains.

Where slavery is legal in one part of a republic but not in the other, as in antebellum America, then the free part represents both a threat and an opportunity for the slave part. It is a threat because it represents a refuge both literally and symbolically for slaves giving them hope that a free way of life for them might exist. ${ }^{59}$ Free states give air to anti-slavery ideals while also providing a challenge to the ambitions of the slaveholders by blocking legislation that is in their interests. At the same time, the free states represent an enormous opportunity for expansion for the lucrative business of slaveholding. The free states cannot contain these conflicting pressures. While it had been tempting, as Douglass puts it, for the people of the

\footnotetext{
56 “Colored Race", 350.

57 Life and Times, 211.

58 Quoted in Stauffer, Black Hearts, 21.
}

59 "To look at the map and observe the proximity of Eastern shore, Maryland, to Delaware and Pennsylvania, it may seem to the reader quite absurd to regard the proposed escape as a formidable undertaking" Douglass tells us, but while "the real distance was great enough, but the imagined distance was, to our ignorance, much greater. Every slaveholder seeks to impress his slave with a belief in the boundlessness of slave territory, and of his own almost illimitable power" (My Bondage, 205, see Life and Times, 110). 
North to ask "what have we to do with slavery?" inactivity inevitably meant the steady loss of power, influence and territory to the South. ${ }^{60}$ The repeal of the Missouri Compromise and the passing of the Nebraska-Kansas Act ceded the balance of political power to the slave states which resulted in actions such as the Dred Scott case and the passing of the Fugitive Slave Law. ${ }^{61}$ Douglass describes the latter as "a bill, undoubtedly more designed to involve the North in complicity with slavery and deaden its moral sentiment, than to procure the return of fugitives to their so-called owners". 62

Slavery, Douglass argues, cannot be appeased and so eventually, the vying between the free and slave parts of America led to the Civil War. This, however, did not end the matter. The political system in the country may have changed but the culture and mentality that supported slavery, he argues, remained wholly intact. Douglass points to the Supreme Court's decision in 1883 to overturn the 1875 Civil Rights Act that had given black citizens equal protections in areas such as public accommodation and transportation, declaring that even "the surrender of the nation's capital to Jefferson Davis in time of war could hardly have caused greater shock" to African Americans so great a setback was it to their ambitions of civil and political equality. ${ }^{63}$ Douglass summarises the situation this way: "While slavery was the baseline of American society, while it ruled the church and state, while it was the interpreter

60 Life and Times, 210.

61 "But they understand us better than we do ourselves, and persevere until the end is gained. No, we would not have Texas - not we - but we had to take her for all that. Then Texas should not have ten millions; but Texas did get ten millions for all that. Then slavery would never go to New Mexico; but slavery is there for all that. We would never hunt slaves under the Fugitive Slave Law; but we do hunt them for all that. They should never repeal the Missouri Compromise; but they did repeal it for all that; and the fact is, history shows that the North has never been able to stand against the power and purposes of the South. Indeed, if compromise could possibly save the Union, the Union could easily be saved; but thanks to the spirit of tyrants, they want no compromise" ("The Future of the Abolition Cause", Writings, vol. 3,83$)$.

62 Life and Times, 199-200.

${ }^{63}$ Life and Times, 395. 
of our law and the exponent of our religion, it admitted no quibbling... But now slavery is abolished. Its reign was long, dark, and bloody. Liberty is now the baseline of the Republic. Liberty has supplanted slavery, but I fear it has not supplanted the spirt or power of slavery. Where slavery was strong, liberty is now weak" ${ }^{64}$ Liberty is weak, he concludes, because the former slave culture was not overturned at the same time as the political institutions and so former prejudices and attitudes have been allowed to creep back in and take over the institutions of state once again.

A republican revolution once begun must be seen through to completion otherwise eventually someone - most likely the members of those groups that were initially dominant - will seize power and everyone's freedom will be diminished. A political revolution alone, such as the declaration of independence in 1776 or the proclamation of emancipation in 1863, is insufficient because it does not change the conceptual framework of the society involved. This latter revolution is a much more difficult, fragile and protracted enterprise and it requires a very different set of skills. "A profounder wisdom", Douglass argues, "a holier zeal, than belongs to the prosecution of war, will be required" to rebuild the social fabric, adding that while "courage and patriotism are chiefly needed now [during the Civil War]... a deep insight into human nature will be needed then". ${ }^{65}$ This task cannot be delegated to or assumed by the formerly dominant group but must necessarily be a collaborative effort inclusive of all social groups. Of course, race is not the only divider in society as Douglass recognises. "The spirit of caste is dangerous everywhere", he says, highlighting the tensions raised by religious, class, gender and ethnic differences. ${ }^{66}$ Nevertheless, while all of these groups must be fully represented in the new republic, it remains the slave whose very presence in the republic was the explicit objective of half the country to keep out and keep down. And so it is their voices that need most urgently to be heard. "No one man can tell the truth", Douglass concludes, "Not even two men of the same complexion, sometimes can tell it. It requires a white man and a black man - as black as he can be - to "tole" the whole truth". ${ }^{67}$

\footnotetext{
${ }^{64}$ Life and Times, 402.

65 "Work of the Future", 290-1.

${ }^{66}$ See "This Decision has Humbled a Nation, Papers, vol. 5, 117.

67 "Good Men are God in the Flesh", Papers, vol. 5, 432.
} 